\title{
Casein synthesis is independently and additively related to individual essential amino acid supply
}

\author{
S. I. Arriola Apelo, ${ }^{\star 1}$ L. M. Singer, ${ }^{\star}$ W. K. Ray,† R. F. Helm, $†$ X. Y. Lin,‡ M. L. McGilliard, ${ }^{*}$ N. R. St-Pierre,§ \\ and M. D. Hanigan* \\ *Department of Dairy Science, and \\ †Department of Biochemistry, Virginia Tech, Blacksburg 24061 \\ $\ddagger$ Animal Science and Technology College, Shandong Agriculture University, 271018, China \\ §Department of Animal Sciences, The Ohio State University, Columbus 43210
}

\begin{abstract}
Specific AA affect rates of milk protein synthesis in the mammary glands of lactating cows. The objective of this study was to quantify the rate of $\alpha_{\mathrm{S} 1}$-casein synthesis in response to Ile, Leu, Met, and Thr supplementation, and to test the single-limiting AA theory for milk protein synthesis by exploring interactions among these AA. Effects of Ile, Leu, Met, and Thr were studied in vitro with a composite design containing a central point repeated 4 times, with 2 axial points per AA and a complete $2^{4}$ factorial. Other AA were at the concentration in Dulbecco's modified Eagle medium/F12 medium (DMEM). The experiment was replicated with mammary tissue from 5 lactating cows. Mammary tissue slices $(0.12 \pm 0.02 \mathrm{~g})$ were incubated for $4 \mathrm{~h}$ at $37^{\circ} \mathrm{C}$ in $5 \mathrm{~mL}$ of treatment medium containing ${ }^{2} \mathrm{H}_{5}$-Phe. Caseins were precipitated from cell homogenate supernatants. Enrichment with ${ }^{2} \mathrm{H}_{5}$-Phe of the N[34]LLRFFVAPFPE $\alpha_{S 1}$ peptide was determined by matrix-assisted laser desorption/ionization-tandem time-of-flight (MALDITOF-TOF), which was used to determine enrichment of Phe in the transfer (t)RNA pool and $\alpha_{\mathrm{S1}^{-}}$-casein fractional synthesis rates (CFSR). Data were analyzed with a polynomial mixed model containing linear, quadratic, and 2-factor interactions for Ile, Leu, Met, and Thr, and cow and residual as random factors. Interactions were not significant at $P<0.1$ and were removed from the model. Increasing concentrations of Ile, Leu, Met, and Thr simultaneously increased CFSR curvilinearly with a predicted maximum response of $4.32 \pm 0.84 \% / \mathrm{h}$ at $63 \%$ of DMEM concentrations. The maximum response to each of the $4 \mathrm{AA}$ was at $71,49,60$, and $32 \%$ of the concentration in DMEM, for Ile, Leu, Met, and Thr, respectively. These values correspond to $270,120,440$, and $140 \%$ the plasma concentrations of Ile, Leu, Met, and Thr observed in lactating cows fed to meet $\mathrm{Na}$ -
\end{abstract}

Received August 26, 2013.

Accepted January 7, 2014.

${ }^{1}$ Corresponding author: sebuy@vt.edu tional Research Council requirements, respectively. The CFSR estimated at those maxima were similar among AA $(3.6 \pm 0.6 \% / h)$. Individual AA effects on CFSR did not correlate with mammalian target of rapamycin (mTOR) signaling. Independent responses of CFSR to individual essential AA observed in this study contradict the single-limiting AA theory assumed in current requirement systems. The saturable responses in CFSR to these $4 \mathrm{AA}$ also highlight the inadequacy of using a fixed postabsorptive AA efficiency approach for determining AA requirements for milk protein synthesis.

Key words: essential amino acid, casein, protein synthesis, mammary gland

\section{INTRODUCTION}

Ruminants are especially efficient in converting lowquality feed into high-quality product (i.e., milk, meat, and wool). This is explained by their synergism with microbes that allow them to degrade cell-wall components, and to incorporate nonprotein $\mathrm{N}$ into carbon skeletons to synthesize AA that mammalian cells cannot. However, when fed typical North American diets, dairy cattle only capture $25 \pm 4 \%$ of dietary $\mathrm{N}$ in milk protein, with the remaining being excreted in feces and urine (Hristov et al., 2004). Furthermore, after duodenal absorption, utilization of microbial and dietary AA is significantly less efficient (43\%; Lapierre et al., 2010) in dairy cattle than in swine and poultry. Nitrogen export to the environment affects soil, water, and air quality, with potential effects on aquatic ecosystems, global warming, and human health (Wolfe and Patz, 2002).

Baker (1996) demonstrated that postabsorptive use of $\mathrm{N}$ in pigs can be up to $85 \%$ efficient when the supply of AA matches tissue needs. Similarly, in lactating cows, the efficiency of conversion of extracted EAA by the mammary glands into casein can be as high as $81 \%$, with even higher values for individual EAA (Guinard and Rulquin, 1994). However, EAA extraction by the mammary glands averages $43 \%$ of that supplied (Hani- 
gan et al., 1992), and EAA not extracted by the glands returns to central circulation and can be catabolized by the liver and other tissues. Metabolizable protein efficiency for milk protein, therefore, is determined by the rate of milk protein synthesis relative to the rates of AA utilization for other processes (Hanigan et al., 1998). Given that extraction rates of EAA by splanchnic tissues appear to be a fixed proportion of total supply (Hanigan et al., 2004a,b), stimulating milk protein synthesis would increase extraction by the mammary glands and reduce recycling to splanchnic tissues, thereby reducing splanchnic removal and increasing postabsorptive efficiency of EAA for milk protein.

Among factors reported to affect casein synthesis rate are insulin (Bellacosa et al., 1998), which reflects systemic energy status, and intracellular AMP:ATP ratios (Hardie, 2004), which is a local indicator of energy status. These 2 factors have been shown to regulate protein synthesis through the mammalian target of rapamycin (mTOR) pathway, which regulates mRNA translation initiation and elongation rates (Mahoney et al., 2009). Essential AA have also been shown to control mTOR phosphorylation and regulate protein synthesis in mammary tissue of lactating cows (Appuhamy et al., 2011a). Among EAA, Leu has been shown to increase $\beta$-lactoglobulin synthesis in mammary epithelial cells (Moshel et al., 2006). In vivo, Leu alone increased milk protein yield curvilinearly, with a maximum estimated at $140 \mathrm{~g} / \mathrm{d}$ of digestible Leu (Rulquin and Pisulewski, 2006). Toerien et al. (2010) did not observe the same effect after $9 \mathrm{~h}$ of jugular infusion of Leu $(1.87 \mathrm{~g} / \mathrm{h})$. However, Leu plasma concentrations in the saline treatment were significantly higher than those observed by Rulquin and Pisulewski (2006). Methionine and Lys increased milk protein yield, but addition of Leu and Ile had no effect (Appuhamy, 2010). In vitro, Ile, Leu, Met, and Thr were the only EAA that had an effect on casein synthesis when removed from the culture medium (Appuhamy et al., 2012). Other than identifying the EAA that affect milk protein synthesis, little is known about quantitative responses to those EAA. Therefore, the objectives of this study were to quantify the effect of Ile, Leu, Met, and Thr on casein synthesis rate in vitro, to determine the relation between casein synthesis and protein signaling responses reported previously (Arriola Apelo et al., 2014), and to explore interactions among these AA on casein fractional synthesis rate (CFSR).

\section{MATERIALS AND METHODS}

Tissue collection, treatment medium preparation, tissue slice incubation, and postincubation processing were performed as previously described (Arriola Apelo et al., 2014). Briefly, mammary tissue slices from 5 lactating dairy cows $(0.121 \pm 0.016 \mathrm{~g})$ were incubated in high glucose $(17.5 \mathrm{mM})$, high insulin $(0.01 \mathrm{mg} / \mathrm{L})$ Dulbecco's modified Eagle medium/F12 medium (DMEM; 0.0215 $\mathrm{m} M$ phenol red), in which Phe was substituted with ${ }^{2} \mathrm{H}_{5}$ Phe (98\% purity; Cambridge Isotope Laboratories Inc., Andover, MA). The effects of Ile, Leu, Met, and Thr on ${ }^{2} \mathrm{H}_{5}$-Phe transfer $(\mathbf{t}) \mathrm{RNA}^{\text {Phe }}$ enrichment and CFSR were studied with a composite design consisting of a central point repeated 4 times, 2 axial points per AA, and a complete $2^{4}$ factorial ( 28 treatments). Preliminary data indicated saturable responses around $50 \%$ of the concentrations in DMEM. Thus, the central points were set at $35 \%$ of the AA concentration in DMEM to center the design in the curvilinear region of the response. Axial points for each AA were set at 0 and $100 \%$ of the concentrations in DMEM, holding the other AA at the central points. Factorial points were set equidistant from central points at 20 and $50 \%$ of DMEM concentrations. Threonine concentrations in treatment media were set to $0,10,17,25$, and $49 \%$ of those in DMEM to better describe response curves based on preliminary data. Two additional treatments with all $4 \mathrm{AA}$ at 0 or $100 \%$ DMEM were added to the experiment to analyze the response to the bulk of AA. For that analysis, the 2 added treatments were used in conjunction with the central points and the 2 factorial treatments with the $4 \mathrm{AA}$ at 20 and $50 \%$ of the concentrations in DMEM (10 and $25 \%$ for Thr; 8 treatments total). The effects of individual EAA and interactions were determined using the 28 treatments of the central composite design, without the 2 treatments with the $4 \mathrm{AA}$ at 0 and $100 \%$ of DMEM concentrations.

Following a 4-h incubation in treatment medium, slices were homogenized in lysis buffer $(7: 1, \mathrm{vol} / \mathrm{wt} ; 50$ mmol of Tris $\mathrm{HCl}, \mathrm{pH} 7.4 ; 150 \mathrm{mmol}$ of $\mathrm{NaCl} ; 1 \mathrm{mmol}$ of EDTA; $1 \mathrm{mmol}$ of phenylmethylsulfonyl fluoride, 1 mmol of $\mathrm{Na}_{3} \mathrm{VO}_{4}, 1 \mathrm{mmol}$ of $\mathrm{NaF}, 0.001 \mu \mathrm{g}$ of aprotinin, $0.001 \mu \mathrm{g}$ of leupeptin, $0.001 \mu \mathrm{g}$ of pepstatin, $10 \mathrm{~mL}$ of Nonidet P-40, and $2.5 \mathrm{~g}$ of Na-deoxycholate per liter) and centrifuged for $5 \mathrm{~min}$ at $16,000 \times g$ at $37^{\circ} \mathrm{C}$. The pellet was discarded.

\section{Intracellular Casein Enrichment}

Liquid chromatography (LC)-MS solvents were from Spectrum Chemical (New Brunswick, NJ). All other reagents were from Sigma-Aldrich (St. Louis, MO) unless indicated otherwise. Caseins were precipitated from media and cell homogenate supernatants, as described by Cuollo et al. (2010) with modifications. Briefly, $100 \mu \mathrm{L}$ of cell lysate was acidified by addition of $100 \mu \mathrm{L}$ of $1 M$ sodium acetate ( $\mathrm{pH} 4.6)$, incubated for $30 \mathrm{~min}$ at $37^{\circ} \mathrm{C}$, and centrifuged for $10 \mathrm{~min}$ at $4,000 \times \mathrm{g}$. Pellets were washed twice with ice-cold $0.15 M$ sodium acetate $(\mathrm{pH}$ 
4.6), twice with ice-cold acetone, and stored at $-80^{\circ} \mathrm{C}$ for analysis. Casein-enriched pellets were suspended in $200 \mu \mathrm{L}$ of $0.5 \mathrm{M}$ ammonium bicarbonate, to which was added endoproteinase Glu-C (80 ng in $180 \mu \mathrm{L}$ of 25 $\mathrm{m} M$ ammonium bicarbonate). Samples were incubated overnight at $37^{\circ} \mathrm{C}$. The following day, $1.5 \mu \mathrm{L}$ of each sample was spotted onto a matrix-assisted laser desorption/ionization (MALDI) target plate and allowed to air dry. Dried sample spots were washed several times with $2 \mu \mathrm{L}$ of $0.1 \%$ trifluoroacetic acid in LC-MS grade water. Sample spots were then overlaid with $1 \mu \mathrm{L}$ of matrix solution, which was allowed to air dry. Matrix

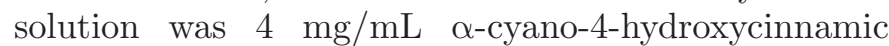
acid prepared in 50:50 acetonitrile:water (both LC-MS grade) supplemented with $0.1 \%$ trifluoroacetic acid and $10 \mathrm{~m} M$ ammonium chloride. Spotted samples were then analyzed in reflector positive ion mode using a MALDI tandem time-of-flight (TOF/TOF) analyzer (AB Sciex, Framingham, MA). A spectrum was obtained for each sample for the mass/charge $(\mathrm{m} / z)$ range of 1400 to 1500, summing 3,000 laser shots. The MALDI control software 4000 series Data Explorer (AB Sciex) was used to export the cluster area values (total area of all isotopic peaks) for the $\alpha_{\mathrm{S}_{1}}$-casein peptide 34-NLLRFFVAPFPE-45 $(m / z=1449.79)$ containing none $(\mathrm{m}+0)$, single $(\mathrm{m}+5)$, double $(\mathrm{m}+10)$, and triple $(\mathrm{m}+15)$ labeled Phe (Supplemental Figure S1; http://dx.doi.org/10.3168/ jds.2013-7422). The cluster area corresponding to the peptide containing one labeled phenylalanine was negligible for all samples analyzed (Supplemental Figure S2). ${ }^{2} \mathrm{H}_{5}$-Phenylalanine casein enrichment was not detected in medium samples (Supplemental Figure S3), indicating that most of the casein synthesized during the incubation period remained within the tissue slice. Intracellular CFSR $(\% / \mathrm{h})$ was estimated as follows:

$$
\operatorname{CFSR}(\% / \mathrm{h})=\frac{100}{4} \times \frac{\frac{m 15}{E_{\text {Phe }_{-} t R N A}{ }^{3}}}{\left(m 0-\frac{m 15}{E_{\text {Phe }_{-} t R N A}{ }^{3}} \times\left(1-E_{\text {Phe }_{-} t R N A}\right)^{3}\right)^{3}},
$$

where $E_{\text {Phe_tRNA }}$ represents the percentage enrichment in the Phe acylated-tRNA pool, $m 0$ represents the area under the curve for $\mathrm{m}+0$, and $m 15$ represents that for $\mathrm{m}+15$. The numerator estimates labeled and unlabeled newly synthesized peptides based on a binomial distribution. The denominator estimates unlabeled peptides already present in the cells at the start of incubation. For this estimation, unlabeled newly synthesized peptides are subtracted from the unlabeled pool.

Transfer RNA enrichment was assessed with an indirect isotopomer method where tRNA ${ }^{\text {Phe }}$ enrichment is equal to the probability that a nascent peptide with 2 ${ }^{2} \mathrm{H}_{5}$-Phe will gain a third ${ }^{2} \mathrm{H}_{5}$-Phe. As mRNA translation is a sequential process, only peptides that have the first and second Phe positions labeled could gain a third ${ }^{2} \mathrm{H}_{5}$-Phe. A nascent peptide with only 1 of the first 2 sites labeled cannot achieve triple labeling regardless of the labeling in the third position. Furthermore, the probabilities of getting a ${ }^{2} \mathrm{H}_{5}$-Phe in any of the 3 positions are independent and equal. Therefore, ${ }^{2} \mathrm{H}_{5}-\mathrm{Phe}$ tRNA $^{\text {Phe }}$ enrichment was indirectly estimated from the prevalence of $\mathrm{m}+15$ and $\mathrm{m}+10$ peptides:

$$
E_{\text {Phe_tRNA }}=\frac{m 15}{m 15+m 10 / 3},
$$

where $m 10$ is the area under the curve for $m+10$ peptides.

\section{Statistical Analysis}

Data were analyzed with the following model:

$$
\begin{gathered}
y_{i j k}=B_{0}+\sum_{i=1}^{4} B_{1_{i}} x_{i}+\sum_{i=1}^{4} \sum_{j=i}^{4} B_{2_{i j}} x_{i} x_{j}+z_{k}+e_{i j k}, \text { and } \\
z_{k} \sim \operatorname{IIDN}\left(0, \sigma_{z}^{2}\right) \text { and } e_{i j k} \sim \operatorname{IIDN}\left(0, \sigma_{e}^{2}\right),
\end{gathered}
$$

where $y_{i j k}$ is the response of the $i$ th and $j$ th $\mathrm{AA}$ and $k$ th cow, and $x_{i}$ represents the concentration of each of the 4 EAA in the medium $(\mathrm{m} M), z_{k}$ represents the random effect of cow, and $e_{i j k}$ the random error. Random effects are independent, identically distributed with normal distribution $(I I D N)$; and $\sigma_{z}^{2}$ and $\sigma_{e}^{2}$ represent the variances of the random effect of cow and residual, respectively. The terms $B_{0}, B_{1}$, and $B_{2}$ correspond with the intercept, linear, and quadratic (plus interaction) parameter estimates, respectively. Model parameters, least square estimates, standard errors, and confidence limits were estimated with the GLIMMIX procedure (SAS 9.3, SAS Institute Inc., Cary, NC). Model selection was performed using backward elimination removing the least significant quadratic or interaction term sequentially until all remaining terms left in the model were significant at $P<0.1$. Nonsignificant linear terms were not removed unless all quadratic terms associated with the linear term were also removed.

\section{RESULTS AND DISCUSSION}

Simultaneous increases in concentrations of Ile, Leu, Met, and Thr had no effect on Phe-tRNA enrichment (Table 1). However, CFSR increased curvilinearly in 
Table 1. Parameter estimates and significance level for the effect of combined changes in Ile, Leu, Met, and Thr concentrations on ${ }^{2} \mathrm{H}_{5} \mathrm{Phe}-\mathrm{tRNA}{ }^{\mathrm{Phe}}$ enrichment ( $\left.\mathrm{E}_{\mathrm{Phe} \text {-tRNA }}\right)$ and $\alpha_{\mathrm{S}_{1}}$-casein fractional synthesis rate (CFSR, $\% / \mathrm{h})$

\begin{tabular}{|c|c|c|c|c|c|c|}
\hline \multirow[b]{2}{*}{ Effect } & \multicolumn{3}{|c|}{$\mathrm{E}_{\text {Phe-tRNA }}$} & \multicolumn{3}{|c|}{ CFSR } \\
\hline & Estimate & $\mathrm{SE}$ & $P$-value & Estimate & $\mathrm{SE}$ & $P$-value \\
\hline Intercept & 0.955 & 0.012 & $<0.001$ & $1.1\left(\mathrm{~h}^{-1}\right)$ & 1.0 & 0.31 \\
\hline ILMT $^{1}$ & $0.009(\mathrm{~L} / \mathrm{mmol})$ & 0.013 & 0.37 & $8.2(\mathrm{~L} / \mathrm{mmol}$ per $\mathrm{h})$ & 1.7 & $<0.001$ \\
\hline ILMT $\times$ ILMT & & & & $-5.2\left(\mathrm{~L}^{2} / \mathrm{mmol}^{2}\right.$ per $\left.\mathrm{h}\right)$ & 1.2 & $<0.001$ \\
\hline
\end{tabular}

${ }^{1}$ ILMT $=$ combined effect of Ile, Leu, Met, and Thr. Included only treatments with Ile, Leu, and Met at 0, $20,35,50$, and $100 \%$, and Thr at $0,10,17,25$, and $49 \%$ of Dulbecco's modified Eagle medium/F12 medium concentrations.

response to the $4 \mathrm{AA}$ (Table 1 and Figure 1), with a predicted maximum response of $4.32 \pm 0.84 \% / \mathrm{h}$ at $63 \%$ of the maximum concentration. The response at $100 \%$ of DMEM concentrations did not differ from that observed at $50 \%$ of DMEM concentrations or at the maximum (95\% confidence limit), suggesting that CFSR reached a plateau.

A large proportion of absorbed AA reaches peripheral circulation (MacRae et al., 1997). In the current study, mammary cells responded in a saturable manner to AA supply. Thus, as supply of AA increases, a smaller proportion of absorbed AA that reaches the glands in vivo will be used for protein synthesis (Whitelaw et al., 1986) and a larger proportion will return to general circulation, where the AA can reach splanchnic tissues and can be catabolized. Splanchnic blood flow is 3 to 4 times that of mammary blood flow (Hanigan et al., 2004b; Raggio et al., 2004), and most

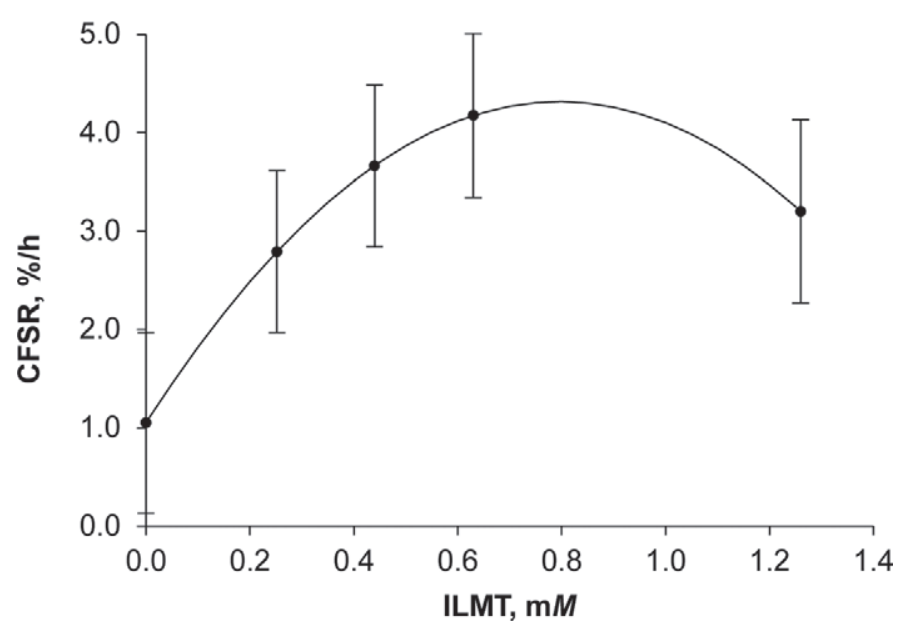

Figure 1. $\alpha_{S 1}$-Casein fractional synthesis rate (CFSR) responses to Ile, Leu, Met, and Thr supply (ILMT). The solid line represents the predicted fractional synthesis rate responses $(\% / \mathrm{h})$ based on the equation $\mathrm{Y}=1.1\left( \pm 1.0 ; P=0.31 ; \mathrm{h}^{-1}\right)+\operatorname{ILMT}(\mathrm{m} M) \times 8.2( \pm 1.7 ;$ $P<0.001 ; \mathrm{L} / \mathrm{mmol}$ per h $)-\mathrm{ILMT}^{2}\left(\mathrm{~m}^{2}\right) \times 5.2( \pm 1.2 ; P<0.001 ;$ $\mathrm{L}^{2} / \mathrm{mmol}^{2}$ per $\left.\mathrm{h}\right)$. Markers indicate least square estimates $( \pm \mathrm{SE})$ at treatment concentrations. Other AA remained at the concentrations in the medium. of the splanchnic use of $\mathrm{AA}$ is proportional to arterial supply (MacRae et al., 1997; Hanigan et al., 2004b). Therefore, at high MP supply levels, MP use efficiency for milk protein will decrease, and AA catabolism by splanchnic tissues and urea production will increase. Decremental responses to AA in CFSR, as reported in this study, agree with the variable animal responses to MP supply reported in the literature (Hanigan et al., 1998; Doepel et al., 2004; Hristov et al., 2004) and are not consistent with the use of a fixed MP partial efficiency for milk protein synthesis as implemented by most nutrient requirement systems. Models based on a fixed partial efficiency over-predict responses as the system approaches the zero-response plateau, a region close to the requirement, and hence the range in which most diets are formulated (Hanigan et al., 1998).

\section{Individual AA Effects on CFSR}

The CFSR model included linear and quadratic terms (Table 2). If the effects in the model were orthogonal, removal of insignificant independent variables would not change the other parameter estimates. However, the treatment design used for this work was not orthogonal (St-Pierre and Weiss, 2009). Therefore, nonsignificant terms were removed iteratively from the equation. The maximum responses to each of the $4 \mathrm{EAA}$ were at 71 , 49,60 , and $32 \%$ of DMEM concentrations for Ile, Leu, Met, and Thr, respectively (Figure 2). Those values correspond to $270,120,440$, and $140 \%$ of observed plasma concentrations of Ile, Leu, Met, and Thr, respectively, in lactating cows fed a $16 \% \mathrm{CP}$ diet (Appuhamy et al., 2011b). The CFSR estimated at those maxima were similar (95\% confidence limit) between EAA (3.6 \pm $0.6 \% / \mathrm{h})$. The CFSR observed for Ile, Met, and Thr at DMEM concentrations did not differ from the maximum response estimated for those EAA and from those observed at $50 \%$ of DMEM concentrations, suggesting that the CFSR response curve started bending at low concentrations and then reached a plateau before the maximum reported for each EAA. The same was not 
Table 2. Parameter estimates for the effects of Ile, Leu, Met, and Thr concentrations on ${ }^{2} \mathrm{H}_{5} \mathrm{Phe}_{\mathrm{PNA}} \mathrm{the}^{\text {Phe }}$

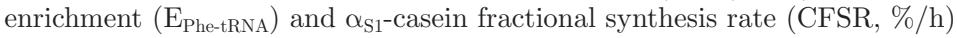

\begin{tabular}{|c|c|c|c|c|c|c|}
\hline \multirow[b]{2}{*}{ Effect } & \multicolumn{3}{|c|}{$\mathrm{E}_{\text {Phe-tRNA }}$} & \multicolumn{3}{|c|}{ CFSR } \\
\hline & Estimate & $\mathrm{SE}$ & $P$-value & Estimate & $\mathrm{SE}$ & $P$-value \\
\hline \multirow[t]{2}{*}{ Intercept } & 0.961 & 0.01 & $<0.001$ & $-1.16\left(\mathrm{~h}^{-1}\right)$ & 0.87 & 0.25 \\
\hline & \multicolumn{3}{|l|}{ - L/mmol - } & \multicolumn{3}{|l|}{ - L/mmol per $\mathrm{h}-$} \\
\hline Ile & -0.134 & 0.07 & 0.046 & 9.3 & 3.2 & 0.005 \\
\hline Leu & & & & 10.2 & 3.0 & 0.001 \\
\hline Met & 0.33 & 0.12 & 0.008 & 28.7 & 7.8 & $<0.001$ \\
\hline \multirow[t]{2}{*}{ Thr } & -0.19 & 0.13 & 0.14 & 21.3 & 6.0 & 0.001 \\
\hline & \multicolumn{3}{|l|}{$-\mathrm{L}^{2} / \mathrm{mmol}^{2}-$} & \multicolumn{3}{|l|}{$-\mathrm{L}^{2} / \mathrm{mmol}^{2}$ per $\mathrm{h}-$} \\
\hline Ile $\times$ Ile & & & & -15.5 & 7.9 & 0.052 \\
\hline Leu $\times$ Leu & & & & -23.3 & 6.9 & 0.001 \\
\hline Met $\times$ Met & -1.47 & 0.70 & 0.038 & -140 & 46 & 0.003 \\
\hline Thr $\times$ Thr & & & & -75 & 27 & 0.007 \\
\hline Ile $\times$ Thr & 1.42 & 0.82 & 0.086 & & & \\
\hline
\end{tabular}

observed for Leu in which the response at DMEM concentrations was lower than those observed at $50 \%$ of DMEM concentrations.

Deleterious effects of AA on CFSR have been previously reported, but not for Leu (Prizant and Barash, 2008). A potential explanation for the decrease in CFSR responses to Leu after the maximum could be that as the response to Leu reached a plateau, high Leu concentrations could have inhibited the transport of other AA that share the same transport system (e.g., Ile). Intracellular concentrations of Ile showed a numerical decrease when compared with Leu concentrations at 0 and $100 \%$ of DMEM (data not shown). In the treatments that belong to the factorial arrangement, Ile varied between 0.084 and $0.21 \mathrm{~m} M$, so they could not be used to determine the effect of Leu. It is worth noting that the maximum Leu response was reached at the lowest concentration when expressed as a proportion of the maximum concentration used. Therefore, more of the Leu response curve was in the saturated region, with no response in CFSR. Previous studies that found an effect of Leu in mammary tissue used a deletion approach, in which the other EAA remained at DMEM concentrations, which may have prevented changes in AA transport from being observed (Appuhamy et al., 2012). The decrease in CFSR observed in response to Leu was not observed when Ile, Met, and Thr were also increased in the medium (Figure 1).

All interactions between EAA were nonsignificant and were removed from the model. Thus, the model predicted the same incremental responses to Ile at any concentration of Leu, Met, or Thr, and vice versa (i.e., additive effects). The type of response predicted by this model in vitro contradicts current concepts in nutrient requirement systems. Dairy nutrient requirement systems are based on the single-limiting AA theory (Mitchell and Block, 1946). This theory was brought to animal nutrition from plant nutrition, and it establishes that a response can only be observed by providing the nutrient that is most limiting relative to requirements (Sprengel, 1828; von Liebig, 1863). Most of the individual nutrient studies in dairy cattle are not designed to challenge this theory. Park et al. (1976) also did not observe significant interactions between 3 groups of EAA on responses of CFSR in mammary tissue of lactating rats. Nonsignificant interactions indicate additive effects between groups of AA and contradict the single-limiting AA theory. Hanigan et al. (2000) observed that curvilinear additive responses to individual EAA explained more variation than a single-limiting AA modeling approach. This observation is in agreement with the model fitted in the present study, where independent curvilinear responses to individual EAA can be predicted. This theory has also been challenged with respect to additive effects of energy and protein on protein synthesis both in vitro and in vivo (Rius et al., 2010; Appuhamy et al., 2011a).

That the mammary glands respond additively to individual AA is significant for diet formulation because one could reduce $\mathrm{CP}$ supply and supplement with individual EAA (e.g., Ile, Met) that specifically stimulate milk protein synthesis to obtain similar levels of milk protein production, reducing markedly $\mathrm{N}$ excretion to the environment. These findings also challenge current nutrient requirement systems because they cannot accommodate a response in milk protein to a correction in the postabsorptive AA profile, except for Met and Lys.

\section{Translation Regulation and CFSR}

Surprisingly, CFSR responses were not correlated with the phosphorylation state of signaling proteins in the mTOR and integrated stress response pathways 

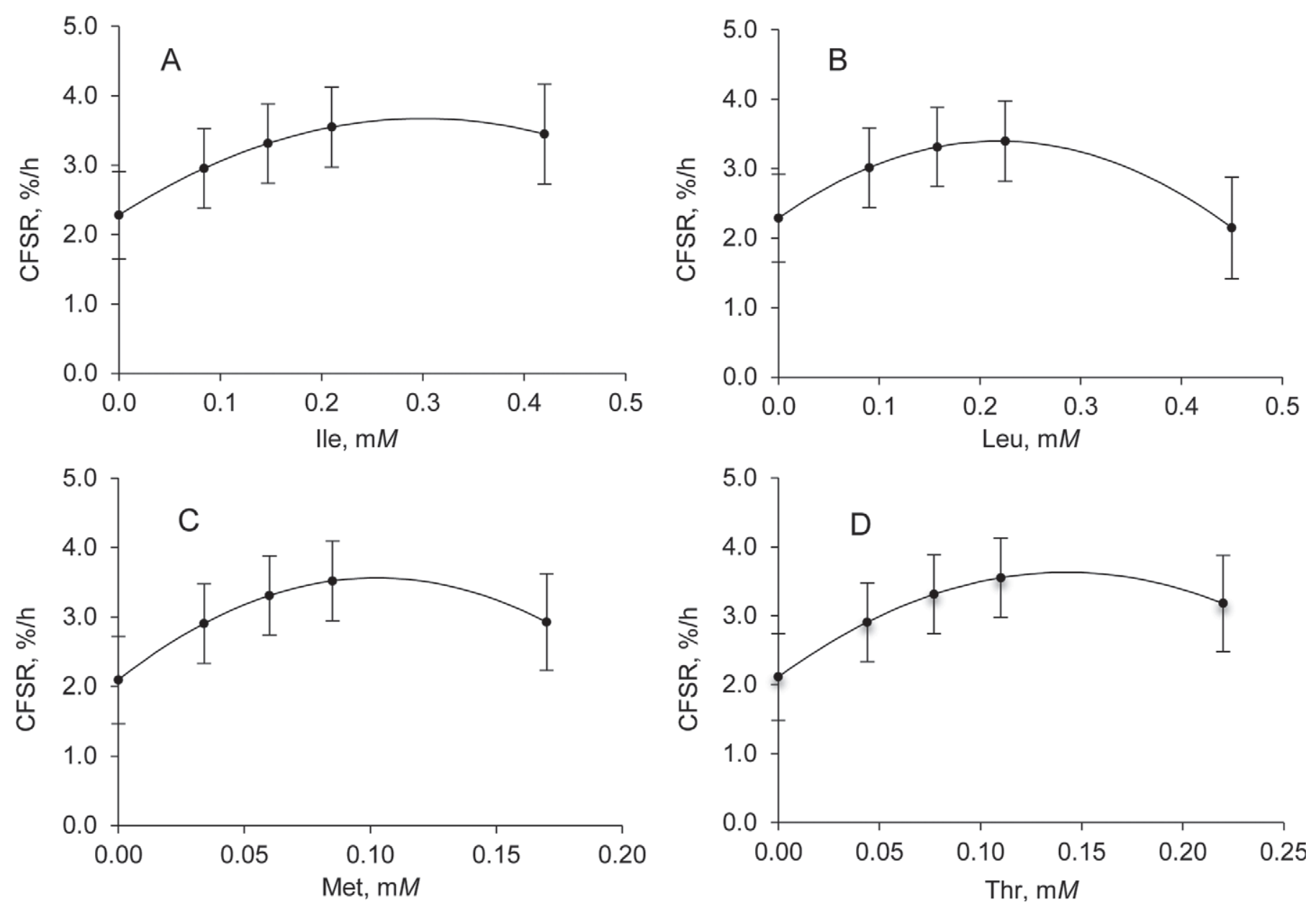

Figure 2. $\alpha_{\mathrm{S} 1}$-Casein fractional synthesis rate (CFSR) responses to concentrations in the medium of (A) Ile, (B) Leu, (C) Met, and (D) Thr. Solid lines indicate predicted values from the CFSR model: $\mathrm{Y}=1.16\left( \pm 0.87 ; P=0.25 ; \mathrm{h}^{-1}\right)+\operatorname{Ile}(\mathrm{m} M) \times 9.3( \pm 3.2 ; P=0.005 ; \mathrm{L} / \mathrm{mmol}$ per $\mathrm{h})$ + Leu $(\mathrm{m} M) \times 10.2( \pm 3.0 ; P=0.001 ; \mathrm{L} / \mathrm{mmol}$ per $\mathrm{h})+\operatorname{Met}(\mathrm{m} M) \times 28.7( \pm 7.8 ; P<0.001 ; \mathrm{L} / \mathrm{mmol}$ per $\mathrm{h})+\mathrm{Thr}(\mathrm{m} M) \times 21.3( \pm 6.0 ; P=$

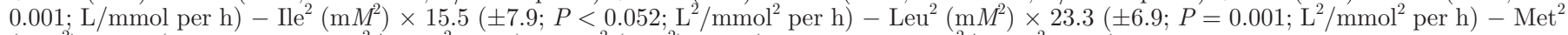
$\left(\mathrm{m} M^{2}\right) \times 140\left( \pm 46 ; P=0.003 ; \mathrm{L}^{2} / \mathrm{mmol}^{2}\right.$ per h $)-\mathrm{Thr}^{2}\left(\mathrm{mM}^{2}\right) \times 75\left( \pm 27 ; P<0.007 ; \mathrm{L}^{2} / \mathrm{mmol}^{2}\right.$ per $\left.\mathrm{h}\right)$. Markers indicate least squares estimates $( \pm \mathrm{SE})$ at treatment concentrations for respective AA, with the other $3 \mathrm{AA}$ held at central concentrations.

reported in Arriola Apelo et al. (2014). These results contradict previous reports of a positive correlation between mTOR activation and CFSR of protein in mammary tissue (Appuhamy et al., 2011a, 2012).

Isoleucine stimulated mTOR and rpS6 phosphorylation linearly (Arriola Apelo et al., 2014). Isoleucine also stimulated CFSR but only up to $0.25 \mathrm{~m} M$ and then it reached a plateau. Therefore, from that point to 0.42 $\mathrm{m} M$, cell signaling increased and there was no further response in CFSR. The response to Ile observed in CFSR could be explained by a substrate effect. However, the mismatch between mTOR activation and CFSR at higher concentrations of Ile raises the question of why protein synthesis reached a plateau when mTOR continued stimulating protein synthesis. One possibility is that the ribosomal translation capacity was exceeded before cell signaling was maximized.
In addition, Met and Thr increased CFSR, but they did not cause the same effect on signaling molecules. Therefore, part of the variation observed in CFSR in response to Met and Thr does not correlate with protein signaling. Further studies are required to explain those results, but it is possible that the effect of these AA is via substrate limitations rather than cell signaling.

\section{Individual AA Effects on tRNA Enrichment}

The model for individual AA effects on tRNA enrichment included linear effects of Ile, Met, and Thr; a quadratic effect of Met; and Ile and Thr interaction (Table 2). The estimate of the intercept was $0.961 \pm$ $0.013(P<0.001)$, indicating that most of the Phe bound to tRNA was labeled. This was expected because the medium did not include any unlabeled Phe. 
The primary source of unlabeled Phe was from release of Phe associated with protein degradation. Tyrosine hydroxylase activity was discounted because ${ }^{2} \mathrm{H}_{4}$-Tyr enrichment was undetectable (data not shown). Hanigan et al. (2009) reported transamination of Phe in the mammary glands, but this did not represent a significant loss of the AA because the ${ }^{13} \mathrm{C}$ labeling was conserved. Thus, a change in tRNA ${ }^{\text {Phe }}$ enrichment could only be explained by changes in the balance of protein synthesis and degradation.

Isoleucine linearly decreased ${ }^{2} \mathrm{H}_{5}$-Phe enrichment of the tRNA ${ }^{\text {Phe }}$ pool $(P=0.05)$. Threonine inhibited the Ile effect on $\mathrm{tRNA}^{\text {Phe }}$ enrichment (Ile $\times$ Thr, $P=0.09$ ). Methionine caused a curvilinear response in $\mathrm{E}_{\text {Phe-tRNA }}$ with the response at $50 \%$ of DMEM concentration significantly higher than that with no Met, but no further responses above $50 \%$ of DMEM concentrations. Leucine had no effect on tRNA ${ }^{\text {Phe }}$ enrichment and was removed from the model.

If individual EAA have no effect on protein degradation (reports to the contrary were not found), a change in tRNA $^{\text {Phe }}$ enrichment would indicate changes in CFSR. The increased AA transport required to support greater CFSR would reduce the relative contribution of unlabeled Phe released from protein degradation. However, if that were the case, tRNA $^{\text {Phe }}$ enrichment should be positively correlated with CFSR, which was not observed (data not shown). Under the same rationale, if treatments have a negative effect on protein degradation in addition to a positive effect on CFSR, the latter should be negatively correlated with tRNA ${ }^{\text {Phe }}$ enrichment. Given that more than $95 \%$ of the Phe-tRNA ${ }^{\text {Phe }}$ was labeled, it is likely that the changes in enriched Phe-tRNA ${ }^{\text {Phe }}$ were below the statistical power of the correlation analysis. Dai et al. (2013) recently reported an effect of Akt on protein degradation, in addition to its effect on mTOR and protein synthesis. Therefore, more research is required to determine if specific EAA that function as signaling molecules could have an effect on protein degradation. Given that little casein is degraded postsynthesis (Wilde et al., 1989) and that Phe in medium dominated intracellular supplies, such regulation should have little effect on CFSR observed in this study.

\section{CONCLUSIONS}

Isoleucine, Leu, Met, and Thr additively stimulated CFSR in vitro, with saturable responses that plateaued at similar levels of protein synthesis. Independent EAA effects on CFSR contradict the single-limiting AA theory assumed in current requirement systems. Saturable responses are inconsistent with the use of a fixed postabsorptive AA efficiency for determining require- ments for milk protein synthesis. Utilizing an approach that reflects saturable independent responses to each of at least these 4 EAA should improve milk protein predictions in nutrient requirement models.

\section{ACKNOWLEDGMENTS}

This project was supported by Agriculture and Food Research Initiative Competitive Grant no. 2012-6701519464 from the USDA National Institute of Food and Agriculture (Washington, DC), and through the NC1040 Multi-state Project. The first author (S. I. Arriola Apelo) received fellowship support from the John Lee Pratt Foundation, Virginia Tech. (Blacksburg).

\section{REFERENCES}

Appuhamy, J. A. D. R. N. 2010. Regulatory roles of essential amino acids, energy, and insulin in mammary cell protein synthesis. PhD Diss. Virginia Polytechnic Institute and State University, Blacksburg.

Appuhamy, J. A. D. R. N., A. L. Bell, W. A. D. Nayananjalie, J. Escobar, and M. D. Hanigan. 2011a. Essential amino acids regulate both initiation and elongation of mRNA translation independent of insulin in MAC-T Cells and bovine mammary tissue slices. J. Nutr. 141:1209-1215.

Appuhamy, J. A. D. R. N., J. R. Knapp, O. Becvar, J. Escobar, and M. D. Hanigan. 2011b. Effects of jugular-infused lysine, methionine, and branched-chain amino acids on milk protein synthesis in high-producing dairy cows. J. Dairy Sci. 94:1952-1960.

Appuhamy, J. A. D. R. N., N. A. Knoebel, W. A. D. Nayananjalie, J. Escobar, and M. D. Hanigan. 2012. Isoleucine and leucine independently regulate mTOR signaling and protein synthesis in MAC-T cells and bovine mammary tissue slices. J. Nutr. 142:484-491.

Arriola Apelo, S. I., L. M. Singer, X. Y. Lin, M. L. McGilliard, N. R. St-Pierre, and M. D. Hanigan. 2014. Isoleucine, leucine, methionine, and threonine effects on mammalian target of rapamycin signaling in mammary tissue. J. Dairy Sci. 97:1047-1056.

Baker, D. H. 1996. Advances in amino acid nutrition and metabolism of swine and poultry. Pages 41-52 in Nutrient Management of Food Animals to Enhance and Protect the Environment. E. T. Kornegay, ed. CRC Press, Boca Raton, FL.

Bellacosa, A., T. O. Chan, N. N. Ahmed, K. Datta, S. Malstrom, D. Stokoe, F. McCormick, J. Feng, and P. Tsichlis. 1998. Akt activation by growth factors is a multiple-step process: The role of the PH domain. Oncogene 17:313-325.

Cuollo, M., S. Caira, O. Fierro, G. Pinto, G. Picariello, and F. Addeo. 2010. Toward milk speciation through the monitoring of casein proteotypic peptides. Rapid Commun. Mass Spectrom. 24:16871696.

Dai, C.-L., J. Shi, Y. Chen, K. Iqbal, F. Liu, and C.-X. Gong. 2013. Inhibition of protein synthesis alters protein degradation through activation of protein kinase B (AKT). J. Biol. Chem. 288:2387523883.

Doepel, L., D. Pacheco, J. J. Kennelly, M. D. Hanigan, I. F. López, and H. Lapierre. 2004. Milk protein synthesis as a function of amino acid supply. J. Dairy Sci. 87:1279-1297.

Guinard, J., and H. Rulquin. 1994. Effect of graded levels of duodenal infusions of casein on mammary uptake in lactating cows. 2. Individual amino acids. J. Dairy Sci. 77:3304-3315.

Hanigan, M. D., C. C. Calvert, E. J. DePeters, B. L. Reis, and R. L. Baldwin. 1992. Kinetics of amino acid extraction by lactating mammary glands in control and sometribove-treated Holstein cows. J. Dairy Sci. 75:161-173.

Hanigan, M. D., J. P. Cant, D. C. Weakley, and J. L. Beckett. 1998. An evaluation of postabsorptive protein and amino acid metabolism in the lactating dairy cow. J. Dairy Sci. 81:3385-3401. 
Hanigan, M. D., L. A. Crompton, C. K. Reynolds, D. Wray-Cahen, M. A. Lomax, and J. France. 2004a. An integrative model of amino acid metabolism in the liver of the lactating dairy cow. J. Theor. Biol. 228:271-289.

Hanigan, M. D., J. France, L. A. Crompton, and B. J. Bequette. 2000. Evaluation of a representation of the limiting amino acid theory for milk protein synthesis. Pages 127-144 in Modelling Nutrient Utilization in Farm Animals. J. P. McNamara, J. France, and D. E. Beever, ed. CABI, Wallingford, UK.

Hanigan, M. D., J. France, S. J. Mabjeesh, W. C. McNabb, and B. J. Bequette. 2009. High rates of mammary tissue protein turnover in lactating goats are energetically costly. J. Nutr. 139:1118-1127.

Hanigan, M. D., C. K. Reynolds, D. J. Humphries, B. Lupoli, and J. D. Sutton. 2004b. A model of net amino acid absorption and utilization by the portal-drained viscera of the lactating dairy cow. J. Dairy Sci. 87:4247-4268.

Hardie, D. G. 2004. The AMP-activated protein kinase pathway-New players upstream and downstream. J. Cell Sci. 117:5479-5487.

Hristov, A. N., W. J. Price, and B. Shafii. 2004. A meta-analysis examining the relationship among dietary factors, dry matter intake, and milk and milk protein yield in dairy cows. J. Dairy Sci. $87: 2184-2196$.

Lapierre, H., C. E. Galindo, S. Lemosquet, I. Ortigues-Marty, L. Doepel, and D. R. Ouellet. 2010. Protein supply, glucose kinetics and milk yield in dairy cows. Pages $275-286$ in Energy and Protein Metabolism and Nutrition. G. M. Crovetto, ed. Wageningen Academic Publishers, Wageningen, the Netherlands.

MacRae, J. C., L. A. Bruce, D. S. Brown, and A. G. Calder. 1997. Amino acid use by the gastrointestinal tract of sheep given lucerne forage. Am. J. Physiol. 273:G1200-G1207.

Mahoney, S. J., J. M. Dempsey, and J. Blenis. 2009. Cell signaling in protein synthesis: Ribosome biogenesis and translation initiation and elongation. Pages 53-107 in Prog. Mol. Biol. Transl. Sci. Vol. 90. W. B. H. John, ed. Academic Press, San Diego, CA.

Mitchell, H. H., and R. J. Block. 1946. Some relationships between the amino acid contents of proteins and their nutritive values for the rat. J. Biol. Chem. 163:599-620.

Moshel, Y., R. E. Rhoads, and I. Barash. 2006. Role of amino acids in translational mechanisms governing milk protein synthesis in murine and ruminant mammary epithelial cells. J. Cell. Biochem. 98:685-700.
Park, C. S., P. T. Chandler, and R. M. Clark. 1976. Optimum amino acid complement for protein synthesis by rat mammary cells in tissue culture. J. Dairy Sci. 59:1758-1763.

Prizant, R. L., and I. Barash. 2008. Negative effects of the amino acids Lys, His, and Thr on S6K1 phosphorylation in mammary epithelial cells. J. Cell. Biochem. 105:1038-1047.

Raggio, G., D. Pacheco, R. Berthiaume, G. E. Lobley, D. Pellerin, G. Allard, P. Dubreuil, and H. Lapierre. 2004. Effect of level of metabolizable protein on splanchnic flux of amino acids in lactating dairy cows. J. Dairy Sci. 87:3461-3472.

Rius, A. G., J. A. D. R. N. Appuhamy, J. Cyriac, D. Kirovski, O. Becvar, J. Escobar, M. L. McGilliard, B. J. Bequette, R. M. Akers, and M. D. Hanigan. 2010. Regulation of protein synthesis in mammary glands of lactating dairy cows by starch and amino acids. J. Dairy Sci. 93:3114-3127.

Rulquin. H., and P. M. Pisulewski. 2006. Effects of graded levels of duodenal infusions of leucine on mammary uptake and output in lactating dairy cows. J. Dairy Res. 73:328-339.

Sprengel, C. 1828. Von den Substanzen der Ackerkrume und des Untergrundes (On the substances in the topsoil and the subsoil). J. Technische Ökonomische Chem. 2:423-474.

St-Pierre, N. R., and W. P. Weiss. 2009. Technical note: Designing and analyzing quantitative factorial experiments. J. Dairy Sci. 92:4581-4588.

Toerien, C. A., D. R. Trout, and J. P. Cant. 2010. Nutritional stimulation of milk protein yield of cows is associated with changes in phosphorylation of mammary eukaryotic initiation factor 2 and ribosomal S6 kinase 1. J. Nutr. 140:285-292.

von Liebig, J. 1863. The Natural Laws of Husbandry. Walton and Maberly, London, UK.

Whitelaw, F. G., J. S. Milne, E. R. Ørskov, and J. S. Smith. 1986. The nitrogen and energy metabolism of lactating cows given abomasal infusions of casein. Br. J. Nutr. 55:537-556.

Wilde, C. J., C. V. P. Addey, and C. H. Knight. 1989. Regulation of intracellular casein degradation by secreted milk protein. Biochim. Biophys. Acta 992:315-319.

Wolfe, A. H., and J. A. Patz. 2002. Reactive nitrogen and human health: Acute and long-term implications. Ambio 31:120-125. 